\title{
Export and its Financing in The SME Segment. Case Study From Slovakia
}

\author{
- Kljucnikov Aleksandr, Popesko Boris
}

\begin{abstract}
The export orientation of small and medium enterprises represents an important attribute of the enterprises' competitive ability. In this context, the area of export financing becomes a very important field of company management. The aim of this study is to define and quantify relevant approaches of entrepreneurs to the export activities and export financing, with regard to the impact of the selected socio-economic factors (gender, level of education and age). The study is based on the research of Slovak business environment carried out in 2016, which was evaluated by the tools of descriptive statistics, including percentages and averages, pivot tables, the methods of comparison and deduction, Pearson's chi-square statistics at 5\% significance level. Our results suggest that Slovak entrepreneurs primarily supply their products and services on the domestic market, while their export potential is limited. The assessment of the state support of export activities is rather negative. An alarming finding is that Slovak entrepreneurs in the SME segment do not use even basic tools of financial risk reduction to a higher extent, and that the usage of services of the state export bank Eximbank is negligible.
\end{abstract}

Keywords: small and medium enterprises, export orientation, export potential of SMEs, export financing, Eximbank

JEL Classification: L 26, O 16, G 32

\section{INTRODUCTION}

The issue of business risks of small and medium enterprises (SMEs) represents a current area of theoretical research and practical applications. Taking into consideration a relatively small size of the Central European countries and a correspondingly small size of the internal markets of these countries, the ability to export products to foreign markets is one of the critical success factors of Central European companies. Because of the historical development of language barriers and cultural contexts, there are many obstacles to the placement of the products of these companies on the global market. A lot of Central European countries have been trying to apply a series of measures that should facilitate the placement of the products of the local companies on foreign markets. These measures include the state support of the means of export financing. Export financing of SMEs is a major problem which determines the current and future performance of these companies, bringing the potential growth of the company, its stability and future (Doležal, 2015).

In this article, we examine significant areas that form the area of export financing. The paper is organized as follows. In the first chapter, we evaluate the results and insights of authors in the concerned field of study. The next chapter introduces the objective of the paper and applied methodology. The results and their economical interpretation are presented in the following chapter. A final part concludes the basic findings of our research. 


\section{THEORETICAL ASPECTS OF SME BUSINESS}

The access to finance and SME export propensity is a recent area of research due to the importance of SMEs in international business activities and also due to their contribution to the economic growth of the country. However, the growth rate and export activities of SMEs are constrained by a lack of financial support from banks and other financial institutions as a result of a higher risk perception of SMEs default probability (Belás et al., 2015, Belás \& Sopkova, 2016, Kolková, 2016, Mura, 2015, Petr, 2016, Vojtovic, 2016). Beck (2013) showed that it is possible to alleviate credit constraints for SMEs by financial deepening, partial credit guarantees, structure of the financial system, regulatory changes and etc. An easy access to finance can enhance exporting activities of the firm, while it was found that firms having strong financial background are in a better position for export (Wagner, 2014). Casser (2004) shows that exporting firms lacking bank finance rely more on their importers' up-front payments to cover up the production costs and other costs related to export. The research also finds that it is easier for the importers to provide finance to the exporters as a result of business relationship (Huyghebaert, 2006). Giannetti et al. (2008) find that financing from the importers is more expensive than the bank financing. However, it is easier for the firms to get finance from the importers due to less administrative work, which is required in case of bank loans.

A wide number of researchers found that export activities of firms can provide a positive sign to the banks while getting bank loans, since by doing international business, a firm can show a superior position in the market in comparison to the other firms (Jinjarak and Wiganraja, 2016). They also find that export activities by SMEs can increase their financial flexibility as they can ask for up-front payments from the international buyers and hence they can rely on the export finance for their financial management.

Bartoli et al. (2014) examined the issue of bank support of SMEs and whether bank support can increase the exporting behaviour of SMEs in the context of Italian market. They found that a long-term relationship with the main bank can lessen financial constraint for the small firms and that can facilitate them to sell more products to the international market as a result of an easier access to finance. They also provided evidence that bank support can help SMEs by facilitating access to credit with lower interest rates and additionally, banks can provide advisory services if the bank is an international bank.

Minetti and Zhu (2011) provide more evidence from the Italian market regarding credit constraints of SMEs and how credit rationing propensity can hamper the export margin of SMEs. The paper finds that the credit rationing can reduce the exporting probability by $39 \%$ and it can also reduce domestic sales of the firms. Hence, suggesting that exporting is not always giving a positive signal to the bank for external finance. Authors argue that it is difficult for banks to evaluate foreign payments and whether it would actually pay off. This uncertainty related to foreign payments leads to reduction of bank loans for exporting SMEs.

Greenaway et al. (2007) examined whether firm's past financial condition helps them in entering an international market and also whether being an exporter can ease the bank financing probability in the UK. The result suggests that an exporter exhibits a better financial condition than a non-exporter, and exporters have a lower leverage with a higher liquidity. Similarly, it is found 
that exporting activities can improve the financial condition of a non-exporter when they start exporting. Hence, the decision to start export activities can be beneficial for firms if they want to increase their financial well-being. They concluded that exporting firms can have an easier access to bank loans as a result of less liquidity constraints and also a better reputation in the market.

Manole and Spatareanu (2010) examined financial constraints of SMEs and exporting activities in the context of the Czech Republic, and found that Czech exporters enjoy more liquidity and they have less credit constraints than non-exporters. It is also found that the industries with high requirements of external finance can have an easier access to bank finance due to having an exporter status. Hence, exporting activities is a positive signal for banks to provide bank loans. However, the paper does not find any evidence that exporting can ease the liquidity constraints for non-exporter, but it is the past financial position of the firms which allows them to export and therefore, the authors confirm that taking export decision is driven by ex-ante financial condition rather than ex-post liquidity improvement.

Goldbach and Nitsch (2014) examined whether export-oriented SMEs use more bank finance than the non-exporters and whether bank finance can enhance the probability of export for German SMEs. The result suggests that bank credit facilities help a firm to expand more on its exporting activities due to financial flexibility. The results also suggest that exporting SMEs are getting about 15\% higher bank credit than the non-exporters and hence, it shows that extra bank financing facilities can foster firms' propensity to do international business. According to the results, the authors argue that export is sensitive to the bank financial support to the SMEs. Therefore, the authors posit that financial flexibility of the firms through bank finance can lower the financial barriers in international business and increase the confidence level of the firm to engage in exporting activities.

Bernard et al. (2010) have utilised a large data set provided by BEEPS survey from 29 countries from Europe and Central Asia to examine the relationship between the bank access to finance and exporting behaviour of SMEs. The paper finds no evidence that external finance and the bank support can increase the exporting tendency of SMEs. The results suggest that SMEs are more comfortable in using the internal funds for the export financing due to a lower level of risk, because it is difficult for the SMEs in transition countries to get bank loans on easier and affordable conditions. They found that international business activities are a game of the firms, that are already in a sound financial condition, rather than of the firms having a liquidity crisis. However, the paper finds a relative support to the statement that export activities can improve the future accessibility of bank finance as export can play the role of a positive signalling device for banks to evaluate a financial position of the firm.

Alvarez and Lopez (2014) examined the use of bank debt by exporting firms and whether bank debt can increase the probability of export in the context of Chile. It is found that firms having external bank finance have a higher propensity to export, and exporting firms need more bank finance than non-exporting ones. It is revealed that about $93 \%$ of exporters in their sample used bank debt versus $77 \%$ of non-exporters. They argued that exporters require more bank finance, as they can experience delays in payments from the importers, and they need to cover the upfront exporting costs. 
Benkraiem and Miloudi (2015) examined the effect of export activities of SMEs on bank access to finance during the global financial crisis in the context of France. The paper finds that during the period of financial crisis, exporting firms had difficulties in getting bank finance due to increased risk and uncertainty of payments from their international buyers. As a result, banks were not comfortable to provide debt to the firms which were actively involved in export. The paper also finds that firms having a need of bank debt for running export activities were affected adversely more than non-exporters. However, if the exporting firms have higher liquidity and solvency ratio, it had a positive effect on bank finance. Hence, the result suggests that during the period of financial crisis the export activities were sending a negative signal while applying for bank loans as a result of increased risk in international business.

Abor et al. (2014) examined the effect of bank finance and firm propensity on export. The result of this paper suggests that there is a significant positive relationship between the bank support in terms of access to finance and firm exporting activities. It was found that those firms that received the bank loans can pay out the substantial amount of capital investment that is required during the period of export and product development. Moreover, the bank support in terms of opening of the letter of credit, receiving payments and forecasting the exchange rate movements can help the SMEs to start international business activities.

\section{RESEARCH OBJECTIVE AND METHODOLOGY}

The aim of the article is to define and quantify significant approaches of entrepreneurs to export activities and export financing of SMEs. In this paper we examine the attitudes of entrepreneurs and quantify significant differences in terms of gender, level of education and age.

The research, focused on the actual situation in Slovak business environment, was carried out in 2016. The questionnaire called Financial Risks of SMEs in Slovakia was distributed online, and is available on the link https://docs.google.com/forms/d/1Fhob6avbfQq4DcaYG44mxNYyohz cqZWDICXkUgFbNq4/view form?c=0\&w $=1$.

The research data were collected by three specific ways. First of all, a random selection of appropriate companies was made from free database of Slovak companies available on www.vsetkyfirmy.sk. The selected companies were contacted by our research team via email. In case that the selected company did not reply on the email, it was contacted by phone. The questionnaire was also placed on the specialized economic web-portals focused on SMEs. Finally, the sample of companies selected by the team experts was contacted directly by researchers themselves. The total number of 438 questionnaires was collected during the research. This number of respondents fulfils the requirements for stochastic selection.

The structure of respondents was as follows: $70 \%$ men, $30 \%$ women; $29 \%$ of respondents reported that they have secondary education, $65 \%$ had a university degree and $6 \%$ reported that they have secondary education without graduation; $66 \%$ of the total number of companies are micro enterprises, $22 \%$ are small enterprises and $7 \%$ are medium-sized enterprises, and $7 \%$ are large enterprises. $48 \%$ of companies' owners stated that the company exists for more than 10 years, $29 \%$ of them stated that it operates for a maximum of five years and $23 \%$ of them reported that the company belongs to an interval of five to ten years of existence. 
In accordance with the recommendation of the European Commission no. 2003/361/EC, we separated microenterprises employing 0-9 employees, small enterprises (10-49 employees) and medium-sized enterprises (50-249 employees) within the category of SMEs in the questionnaire.

The respondents were representing the following sectors: services $(39,74 \%)$ trade $(22,83 \%)$, construction $(13.01 \%)$, manufacturing $(10.05 \%)$, agriculture $(4.79 \%)$, transport $(4.11 \%)$, culture and media $(2.05 \%)$, healthcare $(1.83 \%)$, IT $(1.6 \%)$.

For this paper, we set five alternative working hypotheses by the method of expert estimation. The hypotheses were assigned with the abbreviations of $\mathrm{H} 1$ to $\mathrm{H} 4$. The alternative hypotheses were supplemented by the null hypotheses assuming there were no statistically verifiable differences between the researched factors. Null bypotheses: There are no statistically significant dependences between the chosen factors (gender, level of education of the entrepreneur, age of the entrepreneur) and the chosen field of research.

Null hypothesis $\pi_{1}=\pi_{2}$ so $\pi_{1}-\pi_{2}=0$

Alternative hypothesis $\pi_{1}-\pi_{2} \neq 0$

H1: Less than $50 \%$ of SMEs in Slovakia export their products abroad. There are no statistically significant differences in the structure of responses by gender, level of education and age of entrepreneurs. (Question 12)

H2: Export potential of SMEs in Slovakia is lower than 50\%. There are no statistically significant differences in the structure of responses by gender, level of education and age of entrepreneurs. (Question 54)

H3: Less than 30\% of SMEs perceive the state export support as appropriate. There are no statistically significant differences in the structure of responses by gender, level of education and age of entrepreneurs. (Question 51)

H4: Less than $30 \%$ of SMEs intensively use the tools of financial risk reduction. There are no statistically significant differences in the structure of responses by gender, level of education and age of entrepreneurs. (Question 52)

H5: Less than 30\% of SMEs think that export financing through European banks with the financial support from the state represents a significant competitive advantage when exporting products to less developed countries. There are no statistically significant differences in the structure of responses by gender, level of education and age of entrepreneurs. (Question 53)

Our research used the tools of descriptive statistics, including percentages and averages, pivot tables, the methods of comparison and deduction, Pearson's chi-square statistics at 5\% significance level for the verification of the existence of statistically significant dependences and differences between the selected factors. The calculations were made in MS Excel and in the statistical software available at www.socscistatistics.com. Statistically significant differences in the individual responses were investigated by the means of $Z$-score. The calculations were made through free software available at: http://www.socscistatistics.com/tests/ztest/Default2.aspx 


\section{RESULTS AND DISCUSSION}

The following tables present the results of the survey and own calculations in the field of export, export potential of SMEs in Slovakia and in selected areas of export financing.

Tab: 1 -The structure of export in Slovakia

\begin{tabular}{|c|c|c|c|c|c|c|c|c|c|}
\hline \multicolumn{10}{|c|}{ Does you company export your business products or services abroad? } \\
\hline & \multirow{5}{*}{ Total } & \multirow{5}{*}{ M } & \multirow{5}{*}{$\mathrm{F}$} & \multirow{5}{*}{ UD } & \multirow{5}{*}{ SE } & \multirow{5}{*}{$35-$} & \multirow{5}{*}{$36-45$} & \multirow{5}{*}{$45+$} & $\begin{array}{c}\pi \\
\text { Z-score }\end{array}$ \\
\hline & & & & & & & & & $\mathrm{M} / \mathrm{F}$ \\
\hline & & & & & & & & & UD/SE \\
\hline & & & & & & & & & $35-/ 36-45$ \\
\hline & & & & & & & & & $\begin{array}{c}35-/ 45+36- \\
45 / 45+\end{array}$ \\
\hline \multirow{5}{*}{\multicolumn{9}{|c|}{ Yes, more than $50 \%$ of turnover }} & 0.1010 \\
\hline & & & & & & & & & 0.1868 \\
\hline & & & & & & & & & 0.6527 \\
\hline & & & & & & & & & 0.0232 \\
\hline & & & & & & & & & 0.0102 \\
\hline $\mathrm{n}$ & 64 & 39 & 25 & 37 & 27 & 28 & 22 & 14 & \\
\hline$\%$ & 14.61 & 12.79 & 18.80 & 12.98 & 17.65 & 17.18 & 19.30 & 8.70 & \\
\hline \multirow{5}{*}{\multicolumn{9}{|c|}{ Yes, $25 \%-50 \%$ of turnover }} & 0.8181 \\
\hline & & & & & & & & & 0.2187 \\
\hline & & & & & & & & & 0.5485 \\
\hline & & & & & & & & & 0.6818 \\
\hline & & & & & & & & & 0.8259 \\
\hline $\mathrm{n}$ & 45 & 32 & 13 & 33 & 12 & 15 & 13 & 17 & \\
\hline$\%$ & 10.27 & 10.49 & 9.77 & 11.58 & 7.84 & 9.20 & 11.40 & 10.56 & \\
\hline \multirow{5}{*}{\multicolumn{9}{|c|}{ Yes, $5 \%-25 \%$ of turnover }} & 0.0735 \\
\hline & & & & & & & & & 0.1141 \\
\hline & & & & & & & & & 0.6312 \\
\hline & & & & & & & & & 0.2263 \\
\hline & & & & & & & & & 0.5353 \\
\hline $\mathrm{n}$ & 55 & 44 & 11 & 41 & 14 & 17 & 14 & 24 & \\
\hline$\%$ & 12.56 & 14.43 & 8.27 & 14.39 & 9.15 & 10.43 & 12.28 & 14.91 & \\
\hline
\end{tabular}




\begin{tabular}{|c|c|c|c|c|c|c|c|c|c|}
\hline & & & & & & & & & 0.8103 \\
\hline & & & & & & & & & 0.1645 \\
\hline & out less & $\operatorname{nan} 5 \%$ & turnoy & & & & & & 0.1188 \\
\hline & & & & & & & & & 0.6384 \\
\hline & & & & & & & & & 0.2627 \\
\hline $\mathrm{n}$ & 35 & 25 & 10 & 19 & 16 & 10 & 13 & 12 & \\
\hline$\%$ & 7.99 & 8.20 & 7.52 & 6.67 & 10.46 & 6.13 & 11.40 & 7.45 & \\
\hline & & & & & & & & & 0.7642 \\
\hline & & & & & & & & & 0.9203 \\
\hline & does $\mathrm{n}$ & t export & broad & & & & & & 0.0601 \\
\hline & & & & & & & & & 0.8103 \\
\hline & & & & & & & & & 0.0366 \\
\hline $\mathrm{n}$ & 239 & 165 & 74 & 155 & 84 & 93 & 52 & 94 & \\
\hline$\%$ & 54.57 & 54.10 & 55.64 & 54.39 & 54.90 & 57.06 & 45.61 & 58.39 & \\
\hline$\Sigma$ & 438 & 305 & 133 & 285 & 153 & 163 & 114 & 161 & \\
\hline$\chi^{2}$ & & 0.9283 & & 6.8033 & & 4.6141 & 6.1618 & 9.3039 & \\
\hline$\pi$ & & 0.9205 & & 0.1467 & & 0.3292 & 0.1874 & 0.0539 & \\
\hline
\end{tabular}

Note: M - males, F - females, UD - University degree, SE - Secondary Education, 35- - entrepreneurs are younger than 35, 36-45 - entrepreneurs of the age of 36-45 years, $45+$ - entrepreneurs are over 45 years old.

At the base of our research, we can state, that less than $50 \%$ of Slovak SMEs export their products abroad. $54.57 \%$ of respondents said they do not export their products. This opinion was most intensely expressed by the entrepreneurs under the age of 35 years $(57.06 \%)$ and least strongly by the entrepreneurs aged 36 to 45 .

In the group of entrepreneurs who export their products abroad the largest group consists of those entrepreneurs who export more than $50 \%$ of their production $(14.61 \%)$, followed by the group of entrepreneurs who export $5-25 \%$ of their production $(12.56 \%)$, then the group of 25 $50 \%$ of production $(10.27 \%$ ) and the least important is the group of entrepreneurs who export less than $5 \%$ of its production $(7.99 \%)$.

The group of entrepreneurs who declared that the export from 5 to $25 \%$ of their production $(14.43 \%)$ is dominating in case of male entrepreneurs, while the least important group are entrepreneurs who export less than $5 \%$ of their production. In case of the female entrepreneurs predominant is the group that declared that exports more than $50 \%$ of their production. Least important group is the group of female entrepreneurs export less than $5 \%$ of their production.

The most significant number of entrepreneurs in the age group of 35-45 years old is a group of entrepreneurs who declared that export more than $50 \%$ of their production $(17.18 \% / 19.30 \%)$. In the oldest age group, it is a group of entrepreneurs who export 5 to $25 \%$ of their production (14.91\%). The smallest group in each category consists of entrepreneurs who export less than $5 \%$ of their production $(6.13 \% / 11.40 \% / 7.45 \%)$. 
The values of the test criteria ( $\mathrm{p}$-value $=0.9205 / 0.1467 / 0.3292 / 0.1874 / 0.0539)$ confirmed that there are no statistically significant differences in the overall structure of responses. Similarly, p-values of the Z-score confirmed that there were no statistically significant differences in the selected groups of entrepreneurs. The only exception is the finding that younger entrepreneurs claimed the share of export of more than $50 \%$ more often compared to older entrepreneurs ( $\mathrm{p}$ value $=0.0232 / 0.0102)$ and the entrepreneurs over 45 more frequently answered this question negatively compared to entrepreneurs aged 36 to 45 years ( $\mathrm{p}$-value $=0.0366$ ).

Based on the presented results, we can declare that the hypothesis $\mathrm{H} 1$ has been confirmed.

Tab.2 - Export potential of SMEs

\begin{tabular}{|c|c|c|c|c|c|c|c|c|c|}
\hline \multicolumn{10}{|c|}{ Products or services of my company have export potential. } \\
\hline & \multirow{5}{*}{ Total } & \multirow{5}{*}{ M } & \multirow{5}{*}{$\mathrm{F}$} & \multirow{5}{*}{ UD } & \multirow{5}{*}{ SE } & \multirow{5}{*}{$35-$} & \multirow{5}{*}{$36-45$} & \multirow{5}{*}{$45+$} & $\begin{array}{c}\pi \\
\text { Z-score }\end{array}$ \\
\hline & & & & & & & & & $\mathrm{M} / \mathrm{F}$ \\
\hline & & & & & & & & & $\mathrm{UD} / \mathrm{SE}$ \\
\hline & & & & & & & & & $35-/ 36-45$ \\
\hline & & & & & & & & & $\begin{array}{c}35-/ 45+36- \\
45 / 45+\end{array}$ \\
\hline \multicolumn{10}{|c|}{ 1. Completely agree } \\
\hline $\mathrm{n}$ & 43 & 27 & 16 & 23 & 20 & 19 & 16 & 8 & \\
\hline$\%$ & 9.82 & 8.85 & 12.03 & 8.07 & 13.07 & 11.66 & 14.04 & 4.97 & \\
\hline \multicolumn{10}{|c|}{ 2. Agree } \\
\hline $\mathrm{n}$ & 166 & 126 & 40 & 116 & 50 & 65 & 42 & 59 & \\
\hline$\%$ & 37.90 & 41.31 & 30.08 & 40.70 & 32.68 & 39.88 & 36.84 & 36.65 & \\
\hline $\begin{array}{l}\Sigma \\
(1+2)\end{array}$ & 209 & 153 & 56 & 139 & 70 & 84 & 58 & 67 & $\begin{array}{l}0.1211 \\
0.5485 \\
0.9124 \\
0.0735 \\
0.1285 \\
\end{array}$ \\
\hline$\%$ & 47.72 & 50.16 & 42.11 & 48.77 & 45.75 & 51.53 & 50.88 & 41.61 & \\
\hline \multicolumn{10}{|c|}{ 3. No opinion } \\
\hline $\mathrm{n}$ & 102 & 72 & 30 & 64 & 38 & 40 & 23 & 39 & \\
\hline$\%$ & 23.29 & 23.61 & 22.56 & 22.46 & 24.84 & 24.54 & 20.18 & 24.22 & \\
\hline \multicolumn{10}{|c|}{ 4. I do not agree } \\
\hline $\mathrm{n}$ & 102 & 65 & 37 & 65 & 37 & 33 & 25 & 44 & \\
\hline
\end{tabular}




\begin{tabular}{|l|}
\begin{tabular}{|l|c|c|c|c|c|c|c|c|c|}
\hline$\%$ & 23.29 & 21.31 & 27.82 & 22.81 & 24.18 & 20.25 & 21.93 & 27.33 & \\
\hline 5. I completely disagree \\
\hline $\mathrm{n}$ & 25 & 15 & 10 & 17 & 8 & 6 & 8 & 11 & \\
\hline$\%$ & 5.71 & 4.92 & 7.52 & 5.96 & 5.23 & 3.68 & 7.02 & 6.83 & \\
\hline$\Sigma$ & 438 & 305 & 133 & 285 & 153 & 163 & 114 & 161 & \\
\hline$\chi^{2}$ & & 6.8636 & & 4.6451 & & 2.5907 & 7.8144 & 7.5505 & \\
\hline$\pi$ & & 0.1433 & & 0.3260 & & 0.6285 & 0.0986 & 0.1095 & \\
\hline
\end{tabular}
\end{tabular}

Note: M - males, F - females, UD - University degree, SE - Secondary Education, 35- - entrepreneurs are younger than 35, 36-45 - entrepreneurs of the age of 36-45 years, 45+- entrepreneurs are over 45 years old.

The entrepreneurs in our research confirmed that the export potential of their products and services is relatively low, as only $47.72 \%$ of them claimed that their goods and services have export potential. The highest value of this indicator $(51.53 \%)$ was recorded in case of young entrepreneurs under the age of 35 and the lowest value (41.61\%) was indicated in case of older entrepreneurs over the age of 45 .

P-values of Chi-Squared ( 0.1433 / 0.3260 / 0.6285 / 0.0986 / 0.1095) showed that there were no statistically significant differences in the overall structure of responses by gender, level of education and age of entrepreneurs.

P-values of the Z-score $(0,121 / 0.5485$ / 0.9124 / 0.0735 / 0.1285) showed that there were no statistically significant differences in the positive responses of respondents by gender, level of education and age of entrepreneurs.

\section{The $\mathrm{H} 2$ was confirmed.}

Tab.3 - Adequate support from the state

\begin{tabular}{|c|c|c|c|c|c|c|c|c|c|}
\hline \multicolumn{10}{|c|}{ State adequately supports the export of goods and services. } \\
\hline & \multirow{5}{*}{ Total } & \multirow{5}{*}{ M } & \multirow{5}{*}{$\mathrm{F}$} & \multirow{5}{*}{ UD } & \multirow{5}{*}{ SE } & \multirow{5}{*}{$35-$} & \multirow{5}{*}{$36-45$} & \multirow{5}{*}{$45+$} & $\begin{array}{c}\pi \\
\text { Z-score }\end{array}$ \\
\hline & & & & & & & & & $\mathrm{M} / \mathrm{F}$ \\
\hline & & & & & & & & & $\mathrm{UD} / \mathrm{SE}$ \\
\hline & & & & & & & & & $35-/ 36-45$ \\
\hline & & & & & & & & & $\begin{array}{c}35-/ 45+36- \\
45 / 45+\end{array}$ \\
\hline \multicolumn{10}{|c|}{ 1. Completely agree } \\
\hline $\mathrm{n}$ & 10 & 8 & 2 & 7 & 3 & 6 & 4 & 0 & \\
\hline$\%$ & 2.28 & 2.62 & 1.50 & 2.46 & 1.96 & 3.68 & 3.51 & 0.0 & \\
\hline \multicolumn{10}{|c|}{ 2. Agree } \\
\hline $\mathrm{n}$ & 47 & 27 & 20 & 22 & 25 & 19 & 17 & 11 & \\
\hline$\%$ & 10.73 & 8.85 & 15.04 & 7.72 & 16.34 & 11.66 & 14.91 & 6.83 & \\
\hline
\end{tabular}




\begin{tabular}{|c|c|c|c|c|c|c|c|c|c|}
\hline $\begin{array}{l}\Sigma \\
(1+2)\end{array}$ & 57 & 35 & 22 & 29 & 28 & 25 & 21 & 11 & $\begin{array}{l}0.1471 \\
0.0159\end{array}$ \\
\hline$\%$ & 13.01 & 11.48 & 16.54 & 10.18 & 18.30 & 15.34 & 18.42 & 6.83 & $\begin{array}{l}0.4965 \\
0.0147 \\
0.0032\end{array}$ \\
\hline \multicolumn{10}{|c|}{ 3. No opinion } \\
\hline $\mathrm{n}$ & 188 & 138 & 50 & 129 & 59 & 69 & 43 & 76 & \\
\hline$\%$ & 42.92 & 45.25 & 37.59 & 45.26 & 38.56 & 42.33 & 37.72 & 47.20 & \\
\hline \multicolumn{10}{|c|}{ 4. I do not agree } \\
\hline $\mathrm{n}$ & 154 & 108 & 46 & 100 & 54 & 47 & 42 & 65 & \\
\hline$\%$ & 35.16 & 35.41 & 34.59 & 35.09 & 35.29 & 28.83 & 36.84 & 40.37 & \\
\hline \multicolumn{10}{|c|}{ 5. I completely disagree } \\
\hline $\mathrm{n}$ & 39 & 24 & 15 & 27 & 12 & 22 & 8 & 9 & \\
\hline$\%$ & 8.90 & 7.87 & 11.28 & 9.47 & 7.84 & 13.50 & 7.02 & 5.59 & \\
\hline $\begin{array}{l}\Sigma \\
(4+5)\end{array}$ & 193 & 132 & 61 & 127 & 66 & 69 & 50 & 74 & $\begin{array}{l}0.6171 \\
0.7718\end{array}$ \\
\hline$\%$ & 44.06 & 43.28 & 45.86 & 44.56 & 43.14 & 42.33 & 43.86 & 45.96 & $\begin{array}{l}0.8026 \\
0.5093 \\
0.7263\end{array}$ \\
\hline$\Sigma$ & 438 & 305 & 133 & 285 & 153 & 163 & 114 & 161 & \\
\hline$\chi^{2}$ & & 6.3002 & & 8.3416 & & 4.8448 & 16.8040 & 11.7502 & \\
\hline$\pi$ & & 0.1778 & & 0.7984 & & 0.3036 & 0.0021 & 0.0193 & \\
\hline
\end{tabular}

Note: M - males, F - females, UD - University degree, SE - Secondary Education, 35 - - entrepreneurs are younger than 35, 36-45 - entrepreneurs of the age of 36- 45 years, $45+$ - entrepreneurs are over 45 years old.

The presented results confirm that entrepreneurs in Slovakia negatively assess the state support for export. Only $13.1 \%$ of entrepreneurs evaluate the state export support as appropriate. The highest value of positive assessment was presented by entrepreneurs aged 36 to 45 years $(18.42 \%)$ and the lowest values were measured in case of entrepreneurs who are older than 45 years.

$44.06 \%$ of entrepreneurs negatively evaluated the state support of export activities. The most critical were the entrepreneurs over 45 years $(45.96 \%)$, while the least critical were young entrepreneurs under 35 years of age (42.33\%).

The values of the test criteria have confirmed that there are no statistically significant differences in the overall structure of responses of entrepreneurs according to their gender and level of education. According to the results, there are significant differences in the overall structure of the response in accordance with the age of the entrepreneurs. The entrepreneurs under 35, compared with their older colleagues (over 45 years, $\mathrm{p}$-value $=0.0021$ ) and the entrepreneurs 
aged 36-45 years compared with the ones over 45 years $(\mathrm{p}$-value $=0.0193)$ assessed the state support of export more optimistically.

Statistically significant differences were observed when comparing the positive responses in this field. We found that higher educated people are less optimistic in assessment of the state support of export ( $\mathrm{p}$-value $=0.0159)$ and a degree of optimistic assessment of the export support in case of the entrepreneurs under the age of 35 years in comparison with their colleagues over 45 years is significantly higher ( $\mathrm{p}$-value $=0.0147$ ), similarly as in case of the entrepreneurs aged 36 to 45 and over 45 ( $\mathrm{p}$-value $=0.0032)$.

\section{The first part of the $\mathrm{H} 3$ has been confirmed, but the second part of the $\mathrm{H} 3$ was rejected.}

Tab. 4 - Entrepreneurs intensively use the tools of financial risk reduction

\begin{tabular}{|c|c|c|c|c|c|c|c|c|c|}
\hline \multicolumn{10}{|c|}{$\begin{array}{l}\text { SME entrepreneurs in Slovakia intensively use the tools to limit the financial risks (credit } \\
\text { insurance, factoring, forfeiting, etc.). }\end{array}$} \\
\hline & \multirow{5}{*}{ Total } & \multirow{5}{*}{ M } & \multirow{5}{*}{$\mathrm{F}$} & \multirow{5}{*}{ UD } & \multirow{5}{*}{ SE } & \multirow{5}{*}{$35-$} & \multirow{5}{*}{$36-45$} & \multirow{5}{*}{$45+$} & $\begin{array}{c}\pi \\
\text { Z-score }\end{array}$ \\
\hline & & & & & & & & & $\mathrm{M} / \mathrm{F}$ \\
\hline & & & & & & & & & UD/SE \\
\hline & & & & & & & & & $35-/ 36-45$ \\
\hline & & & & & & & & & $\begin{array}{c}35-/ 45+ \\
36- \\
45 / 45+\end{array}$ \\
\hline \multicolumn{10}{|c|}{ 1. Completely agree } \\
\hline $\mathrm{n}$ & 21 & 8 & 13 & 12 & 9 & 11 & 9 & 1 & \\
\hline$\%$ & 4.79 & 2.62 & 9.77 & 4.21 & 5.88 & 6.75 & 7.89 & 0.62 & \\
\hline \multicolumn{10}{|c|}{ 2. Agree } \\
\hline $\mathrm{n}$ & 67 & 50 & 17 & 44 & 23 & 25 & 23 & 19 & \\
\hline$\%$ & 15.30 & 16.39 & 12.78 & 15.44 & 15.03 & 15.34 & 20.18 & 11.80 & \\
\hline $\begin{array}{l}\Sigma \\
(1+2)\end{array}$ & 88 & 58 & 30 & 56 & 32 & 36 & 32 & 20 & $\begin{array}{l}0.3953 \\
0.7490\end{array}$ \\
\hline$\%$ & 20.9 & 19.02 & 22.56 & 19.65 & 20.92 & 22.09 & 28.07 & 12.42 & $\begin{array}{l}0.2543 \\
0.0214 \\
0.0011\end{array}$ \\
\hline \multicolumn{10}{|c|}{ 3. No opinion } \\
\hline $\mathrm{n}$ & 174 & 118 & 56 & 115 & 59 & 70 & 39 & 65 & \\
\hline$\%$ & 39.73 & 38.69 & 42.11 & 40.35 & 38.56 & 42.94 & 34.21 & 40.37 & \\
\hline \multicolumn{10}{|c|}{ 4. I do not agree } \\
\hline $\mathrm{n}$ & 149 & 112 & 37 & 98 & 51 & 45 & 33 & 71 & \\
\hline$\%$ & 34.02 & 36.72 & 27.82 & 34.39 & 33.33 & 27.61 & 28.95 & 44.10 & \\
\hline
\end{tabular}




\begin{tabular}{|l|c|c|c|c|c|c|c|c|c|}
\hline \multicolumn{2}{|l|}{ 5. I completely disagree } \\
\hline $\mathrm{n}$ & 27 & 17 & 10 & 16 & 11 & 12 & 10 & 5 & \\
\hline$\%$ & 6.16 & 5.57 & 7.52 & 5.61 & 7.19 & 7.36 & 8.77 & 3.11 & \\
\hline$\Sigma$ & 438 & 305 & 133 & 285 & 153 & 163 & 114 & 161 & \\
\hline$\chi^{2}$ & & 13.6668 & & 1.1046 & & 2.5394 & 18.0350 & 21.4253 & \\
\hline$\pi$ & & 0.0084 & & 0.8935 & & 0.6376 & 0.0012 & 0.0003 & \\
\hline
\end{tabular}

Note: M - males, F - females, UD - University degree, SE - Secondary Education, 35- - entrepreneurs are younger than 35, 36-45 - entrepreneurs of the age of 36-45 years, 45+ - entrepreneurs are over 45 years old.

At the base of the presented results, we can conclude that Slovak entrepreneurs in the segment of SMEs do not intensively use the tools of financial risk reduction. Only $20.9 \%$ of entrepreneurs agreed with this statement. The largest group of entrepreneurs, who agreed with this statement, were at the age between 36 and 45 years $(28.7 \%)$, while the least numerous group comprised of entrepreneurs over the age of $45(12.42 \%)$.

The values of the test criteria have confirmed that there are statistically significant differences in the overall structure of responses of entrepreneurs according to gender ( $p$-value $=0.0084$ ) and age of entrepreneurs $(0.0012$ / 0.0003). Statistically significant differences in the overall structure of responses by the level of education of entrepreneurs were not identified.

Statistically significant differences were found when comparing the affirmative replies. Our research results showed that younger entrepreneurs are using the tools to reduce financial risk to a greater extent compared to older entrepreneurs ( $\mathrm{p}$-value $=0.0214 / 0.0011$ ).

The first part of the $\mathrm{H} 4$ has been confirmed, but the second part of the $\mathrm{H} 4$ was rejected.

Tab: 5 Export financing through European banks

\begin{tabular}{|l|c|c|c|c|c|c|c|c|c|}
\hline \multicolumn{2}{|c|}{ Export financing through European banks with the state support provides a distinct com- } \\
petitive advantage for exporting products to less developed markets. \\
\hline
\end{tabular}




\begin{tabular}{|l|c|c|c|c|c|c|c|c|c|c|}
\hline$\%$ & 23.29 & 24.92 & 19.55 & 24.21 & 21.57 & 25.15 & 18.42 & 24.84 & \\
\hline \begin{tabular}{l}
\hline \\
$(1+2)$
\end{tabular} & 116 & 88 & 28 & 79 & 37 & 48 & 26 & 42 & \begin{tabular}{l}
0.0891 \\
0.4237 \\
\\
\hline
\end{tabular} \\
\hline
\end{tabular}

Note: M - males, F - females, UD - University degree, SE - Secondary Education, 35- - entrepreneurs are younger than 35, 36-45 - entrepreneurs of the age of 36-45 years, $45+$ - entrepreneurs are over 45 years old.

The research results show that only $26.48 \%$ of entrepreneurs think that export financing through European banks with the financial support from the state represents a significant competitive advantage when exporting products to less developed countries. Strongly optimistic in this case were the entrepreneurs under 35 years old $(29.45 \%)$ and the lowest level of optimism was reported by the female entrepreneurs (21.05\%).

The values of the test criteria have confirmed that there are statistically significant differences in the structure of responses of entrepreneurs according to their gender ( $\mathrm{p}$-value $=0.0128$ ), level of education ( $\mathrm{p}$-value $<0.0001)$ and age ( $\mathrm{p}$-value $=0.0083 / 0.0013)$. Statistically significant differences in the overall structure of responses of the entrepreneurs younger than 35 and older than 45 were not found.

Statistically significant differences when comparing the positive responses of entrepreneurs by gender, level of education and age were not found, which was confirmed by the values of the test criteria $(\mathrm{p}$-value $=0.0891 / 0.4237 / 0.2187 / 0.4965 / 0.5353)$

\section{The first part of the $\mathrm{H} 5$ was confirmed. The second part of the $\mathrm{H} 5$ was rejected.}

The results of the research show that the access of entrepreneurs to export and export financing to some extent replicates the characteristics of each group of entrepreneurs. It is obvious that the export activity of SMEs is relatively low and the main part of SMEs operates only on 
the local market. Another interesting finding that could have been expected is a lesser degree of an expert orientation in case of the entrepreneurs with a higher age. A similar dependence on age was traced in case of the perception of effectiveness of the state support for exports. In relation to a number of other indicators, however, the research showed no statistically relevant dependencies.

\section{CONCLUSION}

The aim of this paper was to define and quantify significant approaches of the entrepreneurs to export and export financing of SMEs. In this paper, we examined the attitudes of entrepreneurs and quantified the significant differences in terms of gender, level of education and age of the entrepreneurs.

Based on the research results, we can therefore present the following conclusions. Slovak entrepreneurs in the SME segment primarily focus on distribution of their products and services on the domestic market. We found that only $45 \%$ of them export their products abroad. The export potential of their own production was declared by only $48 \%$ of entrepreneurs.

Another finding is the fact that entrepreneurs in Slovakia negatively assess the state support for export activities, as only $13 \%$ of them perceived the state export support as adequate. An alarming finding is that Slovak entrepreneurs in the SME segment do not use even basic tools of financial risk reduction to a higher extent. Only $26 \%$ of entrepreneurs think that export financing through European banks with the financial support from the state represents a significant competitive advantage when exporting the products to less developed countries. The usage of services of the state export bank Eximbank is negligible, while only $10.96 \%$ of entrepreneurs declared the experience with this bank.

Our findings predict the need of optimisation of the instruments of economic policy in Slovakia, since it appears that the export orientation of SMEs is a top perspective direction of the development of economy.

Our study has some limitations that are mainly connected with the number of respondents. In the next studies, we will focus on a more detailed and structured identification of the actual usage of particular financial risk reduction tools in the export financing in order to identify the implications for popularisation of these products by the financial market players.

\section{References}

1. Abor, J. Y., Agbloyyor, E. and Kuipo, R. (2014). Bank finance and export activities of small and medium enterprises. Review of Development Finance, Vol. 4, pp. 97-103. DOI..org/10.1016/ j.rdf.2014.05.004.

2. Alvarez, R. and Lopez, R. A. (2014). Access to bank finance and exporting. Industrial and Corporate Change, 23(6), pp. 1523-1539.

3. Bartoli, F., Ferri, G., Murro, P. and Rotondi, Z. (2014). Bank support and Export: evidence from small Italian firms. Small business Economics, 42, pp. 245-264. DOI:10.1007/s11187-0139486-8. 
4. Beck, T. (2013). Bank financing for SMEs - lessons from the literature. National Institute Economic Review, 225, pp. 39-51. DOI: 10.1177/002795011322500105.

5. Belás, J., Bartoš, P., Hlawiczka, R., Hudáková, M. (2015). Attributes of financial management of family companies in the Czech republic and Slovakia. Family businesses in transition economies: Management, succession and internationalization (pp. 223-238) doi:10.1007/9783-319-14209-8_11

6. Belas, J., Sopkova, G. (2016). Significant determinants of the competitive environment for SMEs in the context of financial and credit risks. Journal of International Studies, 9(2), 139-149. doi:10.14254/2071-8330.2016/9-2/10

7. Benkraiem, R. and Miloudi, A. (2015). How did export activity affect small business access to bank capitals during the global crisis? Corporate Ownership and Control, 11(2 a), pp. 72-80.

8. Bernard, A., Stabilito, A. and Yoo, J, D. (2010). Access to Finance and exporting behaviour in transition countries, Working Paper no. 456, advanced studies in international economic policy research, Kiel Institute for the world economy.

9. Cassar, G. (2004). The financing of business start-ups. Journal of Business Venturing, 19, pp. 261-283.

10. Doležal, J., Šnajdr, J., Belás, J., \& Vincúrová, Z. (2015). Model of the loan process in the context of unrealized income and loss prevention. Journal of International Studies, 8(1), 91-106. doi:10.14254/2071-8330.2015/8-1/8

11. Giannetti, M., Burkart, M. and Ellingsen, T. (2008). What you sell is what you lend? Explaining trade credit contracts. The Review of Financial Studies, 24(4), pp. 1261-1298. DOI: 10.1093/rfs/hhn096.

12. Goldbach, S. and Nitsch, V. (2014). Extra credit: bank finance and firm export status in Germany. The world Economy, 37(7), pp. 883-891.

13. Greenaway, D., Guarigila, A. and Kneller, R. (2007). Financial factors and exporting decisions. Journal of International Economics, 73, pp. 377-395.

14. Huyghebaert, N. (2006). On the determinants and dynamics of trade credit use: Empirical evidence from business start-ups. Journal of Business Finance and Accounting, 33(1), pp. 305-328. DOI: 10.1111/j.1468-5957.2006.001364.x.

15. Jinjarak, Y. and Wiganraja, G. (2016). An empirical assessment of the export- financial constraint relationship: How different are small and medium enterprises. World Development. 79, pp. 152-163.

16. Kolková, A. (2016). Bollinger bands use technical analysis in the forex business. In: Aktuálne problémy podnikovej sféry 2016. Bratislava: Ekonóm, 2016, p. 472-482. ISBN 978-80225-4245-6.

17. Manole, V. and Spatareanu, M. (2010). Exporting, capital investment and financial constraints. Review of World Economics. 146, pp 23-37.

18. Minetti, R. and Zhu, S. C. (2011). Credit constraints and Firm export: Microeconomic evidence from Italy. Journal of International Economics, 83, pp. 109-125. DOI: 10.1016/ j.jinteco.2010.12.004. 
19. Mura, L., Buleca, J., Hajduova, Z., \& Andrejkovic, M. (2015). Quantitative financial analysis of small and medium food enterprises in a developing country. Transformations in Business and Economics, 14(1), 212-224.

20. Petr, P. (2016). Superficiary right of building: Origin and development in central europe. Danube, 7(2), 131-140. doi:10.1515/danb-2016-0008

21. Vojtovic, S., Belas, J., Habanik, J. (2016). Microenterprises' entrepreneurs' attitudes to managing financial risks. Actual Problems of Economics, 186(12), 120-129.

22. Wagner, J. (2014). Credit constraints and exports: A survey of empirical studies using firm level data. Industry and Corporate Change, 23, pp. 1477-1492. DOI: 10.1093/icc/dtu037.

23. Socscistatistic.com (2017, January 20). Social Science Statistics. Retrieved 20 January 2017, from http://www.socscistatistics.com.

24. Socscistatistic.com (2017, January 20). Social Science Statistics. Retrieved 20 January 2017, from http://www.socscistatistics.com/tests/ztest/Default2.aspx.

\section{Contact information}

Ing. Aleksandr Ključnikov, PhD.

Pan-European University in Bratislava

Faculty of Economics and Entrepreneurship

Tomáśikova 20, 82102 Bratislava, Slovakia

Email:kliuchnikov@gmail.com

doc. Ing. Boris Popesko, Ph.D.

Faculty of Management and Economics

Tomas Bata University in Zlin

Mostni 5139, 76001 Zlín, Czech Republic

Email:popesko@fame.utb.cz. 